\title{
Status, abundance and population ecology of Nilgai (Boselaphus tragocamelus Pallas) in Aligarh District, Uttar Pradesh, India
}

\author{
Khursid A. Khan ${ }^{1,2^{*}}$ and Jamal A. Khan ${ }^{1}$ \\ ${ }^{1}$ Department of of Wildlife sciences Aligarh Muslim University, Aligarh 202002 (Uttar Pradesh), INDIA \\ ${ }^{2}$ Bombay Natural History Society, Hornbill House, Opposite Lion gate, Shaheed Bhagat Singh Marg, Mumbai \\ - 400 001(Maharastra), INDIA \\ *Corresponding author. E-mail: khursid.amu@gmail.com
}

Received: March 9, 2015; Revised received: March 20, 2016; Accepted: June 8, 2016

\begin{abstract}
The data on population ecology of nilgai was collected in Aligarh District, Uttar Pradesh, India from August 2013 to June 2014. A total of 108 herds of nilgai 54 in each season (summer and winter) were encountered, respectively. The density of nilgai was found $0.49 / \mathrm{km}^{2}$ in Aligarh district. While the encounter rate was found 0.66 individuals per $\mathrm{km}$. There was a mark seasonal change seen in group size of nilgai i.e. $11.38 \pm 2.76$, and 22.83 \pm 5.40 in winter and summer, respectively. The overall mean group size was found $17.10 \pm 4.08$. The sex ratio of nilgai was female biased, adult male:adult female ratio was found $1: 3$ while overall sex ratio was found $61.55 \%$, $26.32 \%$ and $44 \%$ male, yearling and calves on per 100 females, respectively. The nilgai shows mark seasonal change in their group structure. The group size was found maximum at $25 \%$ in $0-5$ individual category and minimum 9.25 in $>21$ category in winter, while about $30 \%$ were seen in $>21$ category and only $11 \%$ were seen in between $0-5$ category in summer season. Thus, the nilgai was found less sociable in winter and more gregarious in summer season.
\end{abstract}

Key words: Aligarh district, Density, Mean group size, Nilgai, Population structure

\section{INTRODUCTION}

There are 17 mega diverse countries in the world; India is one of the like-minded mega diverse countries. There are about 5488 mammalian species found in the worldwide (IUCN, 2014). India encompasses about 400 mammalian species (Menon, 2014). There are 31 species of ungulates found in India of which 25 ungulate species are protected in Wildlife Protection Act, 1972. There are 6 antelope species, namely Nilgai, Four horned antelope, Indian gazelle, Blackbuck, Tibetan antelope and Tibetan gazelle found in India. Out of these 6 antelope species 3 are endemic to the Indian sub continent. The nilgai or blue bull (Boselaphus tragocamelus) is one of the largest antelope in Indian sub continent (Prater, 1971). Nilgai belongs to the family Bovidae, subfamily Bovinae and tribe boselephini. The populations of several species have declined, some species have been extinct and some are at the verge of extinction due to habitat loss and poaching. While some species have become pest due to their over abundance in some areas. After introduction of Wildlife Protection Act 1972 hunting become totally proscribed for the wild animals and the population of some species which were present out side the protected areas were increased abruptly (Chauhan and Singh, 1990), land use pattern, development in the agriculture, industries and increased urbanization have seriously effected the population of these ecological dislocates (Chauhan and Sawarkar, 1989). The reason for their augment is absence of the natural predator in these areas. Nilgai is one such species which is overabundant in some states of India and it may be regarded as pest (Chopra and Rai, 2009). The encroachment into grasslands by farmers and government policies which consider the grassland and fallow land as the wasteland is another reason of habitat loss and overabundance of these animals. The Aligarh district has no natural forest except the Prosopis plantation. These were planted to stop the invasion of the semi arid region into gangetic planes. This technique is said to be triumphant to check this problem(Hussain , 2014). Therefore the present investigation was conducted to study the status, abundance and population ecology of Nilgai (Boselaphus tragocamelus Pallas) in Uttar Pradesh, India.

\section{MATERIALS AND METHODS}

Study area: The Aligarh district is the one of the western most district of the Uttar Pradesh. It is bounded by the river Ganga and Yamuna for short distances, they forms separately the district from Badaun while the later constituted the dividing line between Aligarh and Gurgaon district of Haryana, bounded in the north by Anoopshaher and khurja tehsil of Bulandshaher district. To the west and south-west lie the Tehsil of Mahabar and Sadabad of Mathura district, while to the 
east and the south-east lie Hathras, Etah and Kasganj district. The extreme parallels of latitude are $27^{\circ} 29^{\prime}$ and $28^{\circ} 11^{\prime}$ north and $77^{\circ} 38^{\prime}$ and $78^{\circ} 38$, east longitude with an area of $3747 \mathrm{~km}^{2}$. The length from east to west is about $112 \mathrm{~km}$ and breadth from north to south is 72 $\mathrm{km}$.

The vegetation of the study area is classified as an arid open scrub commonly known as 'Rakhs' (Champion and Seth, 1968). The vegetation of the study area may be divided into "usarland", Prosopis plantation and agricultural land.

Most of the forest patches are dominated by Prosopis juliflora followed by the other species like Acacia catechu, P. cineraria, P. specigera, Melia azadirachta, Azadirachta indica, Cordia dichotoma, Pongamia pinnata, Syzygium cumini, Dalbergia sissoo, Butea monosperma, Acacia nilotica, Acacia leucophloea and Phoenix sylvestris.

Among the mammalian species Grey wolf (Canis $l u$ pus), Golden jackal (C. aureus), Indian fox (Vulpes bengalensis), Palm civet (Paradoxurus hermaphrodites), Common mongoose (Herpestes edwardsii) and Jungle cat (Felis chaus) are the medium size carnivore found in the study area. Rufous tailed hare (Lepus nigricollis), Indian gerbil (Tatera indica), Five striped palm squirrel (Funambulus pennantii), and Bush rat (Golunda ellioti) Nilgai (Boselaphus tragocamelus) Blackbuck (Antilope cervicapra) and Wild boar (Sus scrofa) rhesus macaque (Macaca mulatta) and Common langur (Presbytis entellus) are found in the study area. (Khan, 1992, Qureshi, 1991; Khan, 2014))

Methodology: Basic information (location of forest patches, their areas and nearby villages) was obtained from the forest department. A questionnaire survey was carried out to know the approximate number of nilgai, activity pattern, crop damage and various methods used by villagers to control the crop damage in 14 villages of Aligarh District. A total of 140 people were interviewed in all these localities. The nilgai population was confined in and around the forest patches and therefore the survey was carried out in the villages which were adjacent to these forest patches. The preferences were given to those villagers who were working in the crop fields during the survey. The selected villages were Nagla Beeriya (Pala sallu), Haivatpur and Kiratpur Nimana (Andala), Kasthali vaishya (Pala Kasthali), Madhawgarh (Junglegarhi), Sikanderpur (Sikandapur Cherat), Shekha (Shekha), Mahua khera and Ghursikaran (Ghursikaran), Ladhawan (Akrabad ladhawan) Kakethal, Nagla kosalpur, Gazipur, and Gijrauli (Atrauli).

Vehicle transect: All the major roads and sub roads were used as transects. A motorcycle was used to carry out the survey. A total of $1541 \mathrm{~km}$ was travelled on 12 major roads and sub roads which were leading towards the adjacent districts. The roads were passing through the Tehsils, blocks, Panchayats, villages, canals, and plantation. These transects were marked on the map and travelled on a monthly basis. During the vehicle transects number of encountering animals, their activity pattern and habitat along with the perpendicular distance were recorded.

Total count: Transects were laid in entire forested patches to count the nilgai (Buckland et al., 1993; Burnham et al., 1980). As nilgai prefers the edges of the forested patches (Sankar, 1994) transects were laid at the edges of the forest patch and later on in the zig zag manner in entire forest patches to count all possible numbers of the nilgai. The number of nilgai along with the age, sex, habitat, activity and perpendicular distance were recorded during the line transects. All nilgai group encountered were classified as (a) An adult male (b) adult female (c) sub adult male (d) sub adult female (e) yearlings and (f) calves.

\section{RESULTS AND DISCUSSION}

A questionnaire survey was carried out to determine the approximate number of nilgai, in 14 villages of Aligarh District. A total of 140 people were interviewd. The numbers of nilgai reported by villagers in their areas in each location were compared with the observed data in each locality. The results were found insignificant $(Z=-2.547, p=0.01)$ because the number of nilgai reported by people was found substantially higher than that of observed in the field. This suggests that the figures reported by villagers appeared to be exaggerated.

Density: Densities of nilgai in India vary widely depending on habitat conditions; competition with domestic livestock, predation, and degree of protection. Table 1 showed the density of nilgai in different forest patches of Aligarh. The density of nilgai was found to be 34 animals per $\mathrm{km}^{2}$ in winter season and it was 42 animals per $\mathrm{km}^{2}$ in summer in same patches. The overall density was found to be 38 animals per $\mathrm{km}^{2}$ in the forest patches. The density was found maximum in and around the Shekha jheel i.e. 132 individuals per $\mathrm{km}^{2}$ followed by the Pala sallu 126 individuals per $\mathrm{km}^{2}$. The density in Shekha is much higher because the protected area is only 25 ha, and the rest of the area is crop land. Nilgai utilizes all the areas including the crop field, but only the protected area is engaged in the density estimation. The minimum density of nilgai was found in the Pala kasthali and Akrabad Ladhawan where the density was 14 and 15 individuals per $\mathrm{km}^{2}$ respectively. Table 2 showed the nilgai densities recorded in different study areas. The nilgai density ranges from 0.43 to 7 individual $/ \mathrm{km}^{2}$. The minimum density was recorded in Pench Tiger Reserve (0.43 individual $/ \mathrm{km}^{2}$ ) and maximum was recorded in Keoladeo National Park (7 individual/ $\mathrm{km}^{2}$ ). The density of nilgai was found to be $0.39-1.47$ individual $/ \mathrm{km}^{2}$ in Gir Lion Sanctuary (Berwick, 1974; Berwick and Jordon 1971, Khan, 1997; Khan, 1996), 0.44-7.81 individual/ $\mathrm{km}^{2}$ in Panna National Park (Chundawat et al., 1999), 6.60-11.36 individual/ $\mathrm{km}^{2}$ in Ranthambhore National Park (Bagchi et al., 2003), 5.67 individual/ $\mathrm{km}^{2}$ in Haryana (Singh, 1995) and 3.93 individual $/ \mathrm{km}^{2}$ 


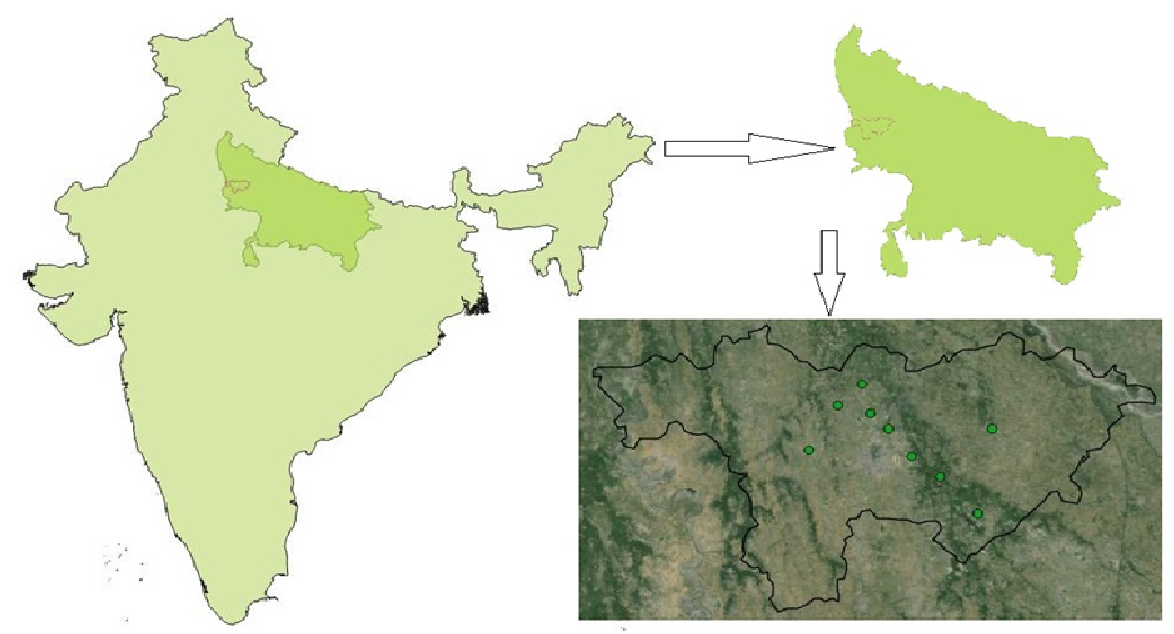

Fig. 1. Showing the study area with forest patches in Aligarh district.

Table 1. Density of Nilgai in different forest patches of Aligarh district.

\begin{tabular}{|c|c|c|c|c|c|c|c|c|}
\hline S.N. & Block Name & Name & $\begin{array}{l}\text { No. of Nilgai } \\
\text { in Winter } \\
\text { (Mean) }\end{array}$ & $\begin{array}{l}\text { No. of Nil- } \\
\text { gai in Sum- } \\
\text { mer (Mean) }\end{array}$ & Area (ha) & $\begin{array}{l}\text { D/ha in } \\
\text { winter }\end{array}$ & $\begin{array}{l}\text { D/ha in } \\
\text { summer }\end{array}$ & $\begin{array}{l}\text { Overall } \\
\text { density/ } \\
\text { ha }\end{array}$ \\
\hline & Gabhana & Pala Sallu & 46 & 61 & 42.11 & 1.09 & 1.44 & 1.265 \\
\hline & Jawan & Jungle Gadhi & 27 & 26 & 102.21 & 0.26 & 0.25 & 0.255 \\
\hline & Jawan & Kasthali Vaisya & 14 & 15 & 90.28 & 0.15 & 0.16 & 0.155 \\
\hline & Lodha & Ghursikaran & 58 & 45 & 178.06 & 0.32 & 0.25 & 0.285 \\
\hline & Akrabad & Akrabad Ladhawa & 18 & 24 & 140.11 & 0.12 & 0.17 & 0.145 \\
\hline & Lodha & Andla & 55 & 51 & 70.12 & 0.78 & 0.72 & 0.75 \\
\hline & Jawan & Sikandarpur (C) & 18 & 20 & 67.20 & 0.26 & 0.29 & 0.275 \\
\hline & Dhanipur & Shekha & 22 & 44 & 25 & 0.88 & 1.76 & 1.32 \\
\hline & Atrauli & Gazipur & 26 & 58 & 101.21 & 0.25 & 0.57 & 0.41 \\
\hline & & Total & 284 & 344 & 816.30 & 0.34 & 0.42 & 0.38 \\
\hline
\end{tabular}

Table 2. Density (No. $/ \mathrm{km}^{2}$ ) of nilgai in different areas in India.

\begin{tabular}{|c|c|c|c|c|c|}
\hline S.N. & Locations & Density & Encounter rate & Mean group size & Investigators \\
\hline & Pench & 0.43 & $\overline{\mathrm{NA}}$ & NA & Biswas and Sankar (2002) \\
\hline & Gir & 0.58 & NA & 1.9 & Khan (1996) \\
\hline & Sariska & 5.19 & 0.41 & 2.4 & Sankar (1994) \\
\hline & Ranthambore & 6.98 & NA & 2.9 & Bagchi et al. (2003) \\
\hline & Keoladeo & 7.00 & NA & NA & Haque (1990) \\
\hline & Haryana & 5.67 & NA & 5.97 & Singh (1995) \\
\hline & Panna & 6.02 & NA & NA & Chundawat et al. (1999) \\
\hline & Kuno & 3.93 & NA & NA & Benerjee (2005) \\
\hline & Aligarh (Present study) & 0.49 & 0.66 & $17.10 \pm 4.08$ & Khan (2014) \\
\hline
\end{tabular}

Table 3. Population structure of Nilgai in Aligarh District.

\begin{tabular}{lllllllllll}
\hline S.N. & Location & Herd & AM & AF & SAM & SAF & Yearling & Calves & Un Id & Total \\
\hline 1. & Pala Sallu & 17 & 32 & 96 & 32 & 66 & 26 & 82 & 0 & 334 \\
2. & Andla & 14 & 49 & 60 & 37 & 55 & 36 & 46 & 0 & 283 \\
3. & Pala Kasthali & 5 & 6 & 19 & 4 & 10 & 4 & 10 & 0 & 53 \\
4. & Jungle Gadhi & 8 & 17 & 32 & 13 & 25 & 16 & 24 & 0 & 127 \\
5. & Sikandarpur $\odot$ & 9 & 12 & 18 & 10 & 20 & 12 & 19 & 1 & 92 \\
6. & Shekha & 8 & 22 & 37 & 27 & 30 & 25 & 32 & 2 & 175 \\
7. & Ghursikarn & 15 & 37 & 61 & 25 & 41 & 23 & 40 & 2 & 229 \\
8. & Akrabad Ladhawa & 7 & 15 & 22 & 9 & 14 & 11 & 14 & 0 & 85 \\
9. & Atrauli & 9 & 26 & 39 & 27 & 26 & 22 & 30 & 0 & 170 \\
10. & Road Side & 16 & 33 & 82 & 28 & 56 & 38 & 59 & 1 & 297 \\
& TOTAL & 108 & 249 & 466 & 212 & 343 & 213 & 356 & 6 & 1845 \\
\hline
\end{tabular}

$\mathrm{AM}=$ Adult male, $\mathrm{AF}=$ Adult female, $\mathrm{SAM}=$ sub adult male, $\mathrm{SAF}=\mathrm{Sub}$ adult female, $\mathrm{Un} . \mathrm{Id}=$ Unidentified individuals 
Table 4. Sex ratio of Nilgai in Aligarh District.

\begin{tabular}{lllll}
\hline S.N. & Location & Males & Yearlings & calves \\
\hline 1. & Pala Sallu & 39.50 & 16.04 & 50.61 \\
2. & Andla & 85.21 & 31.30 & 40.00 \\
3. & Pala Kasthali & 41.37 & 13.79 & 34.48 \\
4. & Jungle Gadhi & 59.64 & 28.07 & 42.10 \\
5. & Sikandarpur ${ }^{-}$ & 63.15 & 31.57 & 50.00 \\
6. & Shekha & 65.67 & 37.31 & 47.76 \\
7. & Ghursikarn & 72.54 & 22.54 & 39.21 \\
8. & Akrabad Ladhawa & 83.33 & 30.55 & 38.88 \\
9. & Atrauli & 80.00 & 33.84 & 46.15 \\
10. & Road Side & 47.82 & 27.53 & 42.75 \\
& TOTAL & 61.55 & 26.32 & 44.00 \\
\hline
\end{tabular}

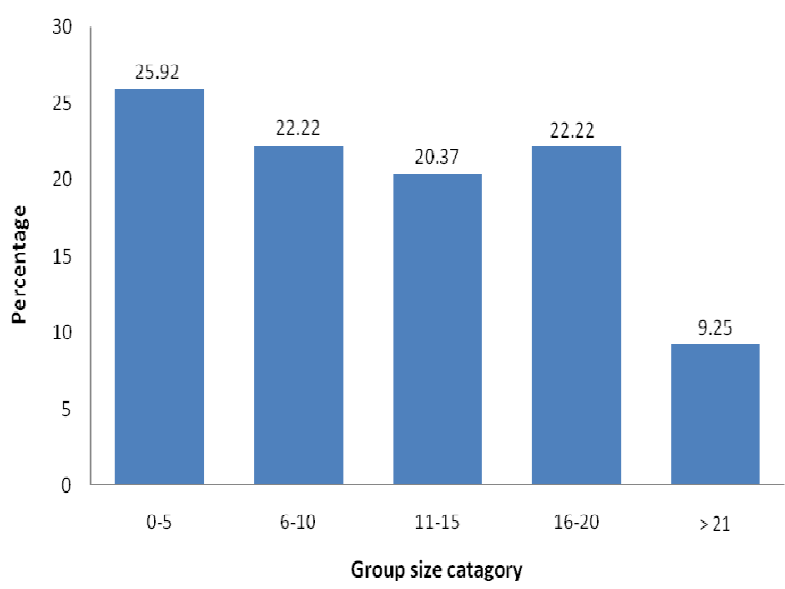

Fig. 2. Percentage of animals in different group size categories in winter season.

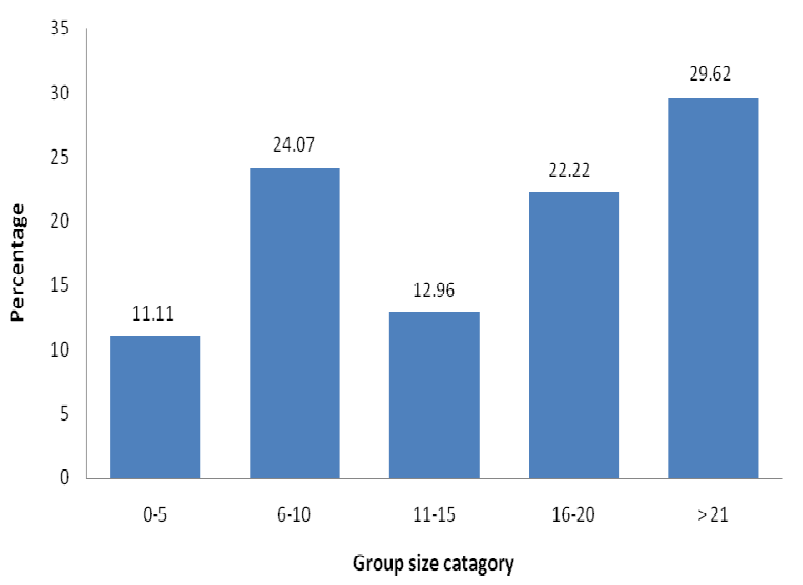

Fig. 3. Percentage of animals in different group size categories in summer season.

\section{Datasheet for questionnaire survey of Nilgai:}

Date: Village: Lat. Long.

Demographic \& Socio- economic profile:

1. Name of respondent:

5. Number of people in the family:

$$
\begin{array}{ll}
\text { A. Males: } & \text { B. Females: }
\end{array}
$$

2. $\mathrm{M} / \mathrm{F}$ :
Tehsil :

Block:

6. Number of Literate family members:

7. Number of family members in working age-

$$
\text { A. Working Male: B. Working Female: }
$$

\begin{tabular}{|c|c|c|c|c|}
\hline Occupation & No. & Occupation & No. & Employment in days/yr \\
\hline Govt. Service & & Labour & & \\
\hline $\begin{array}{l}\text { Pvt. Service } \\
\text { Other }\end{array}$ & & Agriculture & & \\
\hline
\end{tabular}

8. Occupation:

9. Land holding in ha: Yes/No
A. Landless:
B. Marginal:
C. Small (1-2):
D. Semi medium (2-4)
E. Medium 4-10
F. Large: $(>10)$

10. Cropping pattern:
A. Rabi:
B. Kharif:
C. Both:

11. Involvement of men and women in Agricultural activity:
A. Only men:
B. Only women:
C. Both:

12. Estimated number of Nilgai seen in this area:

13. Human wildlife Conflict: Yes/No

14. Crop raided by wild animal:
A. Blackbuck
B. Nilgai
C. Wild boar
D. None

15. Maximum crop damaged by:
A. Blackbuck
B. Nilgai
C. Wild boar
D. None:

16. Scaring devices use
A. Scaring crow:
B. Prosopis fences:
C. Colourful ribbons:
D. Drum sound
E. Wire fences:
F. Firearms
G. Fire 
in Kuno Wildlife Sanctuary (Banerjee, 2005). All the above studies were conducted inside the protected areas except (Singh, 1995); estimated 5.67 individual/ $\mathrm{km}^{2}$ in Haryana. While in Aligarh district the density was found 0.49 individual $/ \mathrm{km}^{2}$. The density is lower than the study conducted in Haryana and this is due to the population of the Aligarh district is much higher in respect of the area. The forested area in Haryana is $1684 \mathrm{~km}^{2}$ while the forested area in Aligarh is only $23.48 \mathrm{~km}^{2}$.

Encounter rate: The encounter rate was found maximum on Atrauli - Pali road (0.86) followed by 0.82 individuals per $\mathrm{km}$ on Aligarh - Khair road and the minimum was in Aligarh - Gonda road i.e. 0.16 individuals per $\mathrm{km}$ in winter season. The overall encounter rate was 0.41 individuals per $\mathrm{km}$ in winter season. Nilgai group were not sight on Aligarh - Jawan and Aligarh - Iglas road during the winter. The encounter rate was found maximum on Aligarh - Khair road 2.55 and minimum 0.11 individuals per $\mathrm{km}$ in Aligarh - Jawan road. The overall encounter rate was found 1.01 individuals per $\mathrm{km}$ in summer season. The overall encounter rate in Aligarh district was found 0.66 individuals per $\mathrm{km}$. The encounter rate of the nilgai was found maximum in the Aligarh- Khair road because these areas enclose small patches of forest and people of these areas have hard religious feeling regarding the nilgai.

Mean group size: A total of 108 groups comprising of 1845 individuals was recorded and the mean group size was found to be $17.10 \pm 4.08$. The maximum number of individuals were recorded in Pala sallu (61) while the minimum was in Sikandarpur Cherat (1).

54 groups of nilgai were recorded in winter, comprising 612 individuals and the mean group size was found to be $11.38 \pm 2.76$ with maximum number recorded in Ghursikarn (58) and minimum on road sides (13). The maximum mean group size was found in Pala sallu $12.81 \pm 2.19$ and minimum in Sikandarpur Cherat $(7 \pm 2)$ in winter season. 54 groups were also recorded in summer season, which comprising of 1233 individuals. The mean group size was $22.83 \pm 5.40$. Mean group size was found maximum in Pala sallu $(32.16 \pm 7.87)$ and minimum in Sikandarpur Cherat $(14.25 \pm 3.06)$. There is seasonal change in mean group size of the nilgai. Nilgai is less gregarious in winter and gregarious in summer. Adult males segregate from females and sub adults during non breeding seasons. Annual group sizes in India are 1.92 individuals (Bagchi et al., 2004; Berwick 1974; Khan, 1996); in Gir mean group size was 1.9 (Khan, 1996); in Sariska 2.4 individuals (Sankar, 1994); in Ranthambhor 2.9 individuals (Bagchi et al., 2003) and in Haryana 5.97 (Singh, 1995). The mean group size was higher than other studies because the nilgai were congregated in the forest patches. This congregation is due to the protection from the farmers as they chase and harass the nilgai to avoid the crop damage. In summer the herd of 35 to 40 individuals were continuously seen in Atrauli, Pala
Sallu and Andla.

Population structure: Table 3 showed overall population structure of nilgai in Aligarh district. A total of 54 groups of nilgai were encountered during winter season, which comprised of 612 individuals. There were 70 adult males, 65 sub adult males, 174 adult females, 98 sub adult females, 52 yearlings, 147 calves and 6 were unidentified. The maximum numbers were recorded in Pala sallu (147 individuals) followed by Ghursikarn (90), while the minimum was recorded in Pala kasthali (24 individuals). A total of 1233 individuals in 54 groups were recorded in summer, which comprised of 179 adult males, 147 sub adult males, 292 adult females, 245 sub adult females, 161 yearlings and 209 calves.

Overall 108 groups were encountered in Aligarh district, in which 1845 individuals were recorded. These comprise of 249 adults, males, 212 sub adult males, 466 adult females, 343 sub adult females, 213 yearlings and 356 calves.

Sex ratio: Table 4 showed the data of overall sex ratio. The male - female ratio was 50:100, female to yearling ratio was 100:19 while the female - calf ratio was 100:54 in winter season. The maximum male to female ratio was found in Atrauli 92:100 and minimum 33:100 in Pala sallu. The maximum number of yearling - female ratio was recorded on road sides (46:100) and minimum in Pala sallu (7:100). The maximum number of calves- cow ratio was recorded in Shekha 78:100 and minimum 38:100 in Ghursikarn, in winter season. While in summer the male - female ratio was 61:100, female - yearling ratio was 100: 30 and calf cow ratio was 39:100. The maximum male to female ratio was found in Akrabad (94:100) and minimum in Pala kasthali (33:100). The maximum number of yearling - female ratio was recorded in Akrabad 44:100 and minimum 20:100 in Pala kasthali, the maximum number of calves - cow ratio was recorded in Atrauli 45:100 and minimum 30:100 in Andla, in winter season.

The overall sex ratio of the male - female was 62:100, yearling to female ratio was $26: 100$ and calf cow ratio was $44: 100$. The male female ratio was the maximum in Andla (85:100) and minimum in Pala kasthali (41:100). The maximum number of yearling female ratio was recorded in Shekha $(37: 100)$ and minimum in pala kasthali (14:100), while the calf cow ratio was maximum in Pala sallu $(51: 100)$ and minimum in Pala kasthali (34:100).

Fig. 2 and 3 provide the percentage of animals in different group size categories. $26 \%$ groups comprised of 0-5 group category, $22 \%$ comprised of 6-10 group category, $20 \%$ were in the 11-15 group category, $22 \%$ in 16-20 group category and $10 \%$ in $>21$ group category in winter season. While in summer $11 \%$ groups were comprised of 0-5 group category, $24 \%$ comprised were 6-10 group category, $13 \%$ were in the $11-15$ group category, $22 \%$ in 16-20 group category and $30 \%$ in $>21$ group category. In India, the sex ratio 
(male:female) of free ranging adult nilgai favours females: 0.59:1 in Bharatpur (Schaller, 1967), 0.39:1 in Vanvihar Sanctuary (Schaller, 1967), and 0.4:1 in Sariska (Sankar, 1994), 0.89:1 (Berwick and Jordan 1971) to 0.71:1 (Khan et al., 1995). In Texas, the observed male:female ratio was 0.81:1 (Sheffield et al., 1983). The female:calf ratios for free-ranging nilgai are: 1:0.23 in Gir (Khan et al., 1995), 1:0.48 in Sariska (Sankar, 1994), and 1:1.03 in Texas (Sheffield et al., 1983). In Aligarh the male: female ratio was also female biased, i.e. $0.61: 1$. The ratio of yearlings- females were very low $(0.26: 1)$ due to high mortality in calves, either due to accidents or due to natural deaths. The calf: female ratio was $0.44: 1$ in Aligarh. High rates of mortality are common for males in particular, but also females, before age 3 (Berwick, 1974; Brown, 1976). In Gir Forest, India, 34\% of calves die each year, and there is a general linear decline of $52 \%$ of $2-10$-yearolds of both sexes (Berwick, 1974).

\section{Conclusion}

This is the first study carried out on nilgai in gangetic plane, except the study carried out in Haryana. The gangetic plane is one of the major crop raided area by wild animals specially by nilgai. Crop raiding in gangetic plane is one of the major concern now a day. The government permitted culling of the nilgai in many central and northern states to regulate crop damage. It is important to know about the status and distribution of wild animals before taking such kind of decision. The density of nilgai is found to be $0.49 / \mathrm{km}^{2}$, encounter rate was found 0.66 induvidual per $\mathrm{km}$ and mean group size was estimated $17.10 \pm 4.08$. The male - female ratio is found to be 62:100, yearling to female ratio was 26:100 and calf - cow ratio was found 44:100 in Aligarh district.

\section{ACKNOWLEDGMENTS}

We are thankful to the DST Purse Programme for funding and Department of Wildlife Science for logistic support. KAK is thankful to Abhishekh, Rohit chaudhary, Amjad and Mujahid for their support in data collection. KAK is also thankful to Dr. Asad R. Rahmani for his immense support and inspiration to write this paper.

\section{REFERENCES}

Bagchi, S. Goyal, S.P. and Sankar, K. (2003). Prey abundance and prey selection by tigers in semi arid, dry deciduous forest in western India. Journal of Zoology (London) 260:285-290.

Bagchi, S., Goyal, S.P. and Sankar, K. (2004). Herbivore density and biomass in a semi-arid tropical dry deciduous forest of western India. Journal of Tropical Ecology 20: $475-478$

Banerjee, K. (2005). Estimating the ungulate abundance and developing the habitat specific effective strip width models in Kuno Wildlife Santuary, Madhya Pradesh. Ph.D. Thesis, FRI University, Dehradun.

Berwick, S.H. (1974). The community of wild ruminants in the Gir forest ecosystems, India. Ph.D. Dissertation, Yale University, New Haven. 266 pp.

Berwick; S.H., and Jordan, P.A. (1971). First report of the Yale-Bombay Natural History Society studies of wild ungulates at the Gir Forest, Gujarat, India. Journal of Bombay Natural History Society 68: 412-423.

Biswas, S. and K. Sankar (2002). Prey abundance and food habit of tigers (Panthera tigris tigris) in Pench National Park, Madhya Pradesh, India. Journal of Zoology 256: 411-422.

Brown, B.A. (1976). The population dynamics of nilgai in southern Texas with some management consideration. Ph.D. Dissertation, Texas A\&M University, College Station.

Buckland, St., Anderson, D.R., Burnham, K.P. and Laake, J.L. (1993). Distance sampling: estimating abundance of biological population. Chapmann and Hall, New York.

Burnham, K.P., Anderson, D.R. and Laake, J.L. (1980). Estimation of density from line transect sampling of biological population. Wildlife Monograph 72: 1-202.

Champion, H. G. and Seth, S. K. (1968). A Revised Survey of Forest Types of India, Government of India Press, New Delhi, 404 pp.

Chauhan, N.P.S and Singh R. (1990). Crop damage by overabundant population of nilgai and blackbuck in Haryana (India) and its management. In vertebrate pest controle conference, Sacromento, California, USA.

Chauhan, N.P.S and Sawarkar, V.B. (1989). Problem of over abundant population of nilgai and blackbuck in Haryana and Madhya Pradesh and their management. Indian Forester 115: 488-493.

Chundawat, R.S., Gogate, N. and Johnsingh, A.J.T. (1999). Tigers in Panna: preliminary results from an Indian tropical dry forest. In Riding the tiger: tiger conservation in human-dominated landscapes: 123-129. Seidensticker, J., Christie, S. and Jackson, P. (Eds). Cambridge: Cambridge University Press.

Chopra, G. and Rai, D. (2009). A study on the ecology of Nilgai (Boselaphus tragocamelus Pallas) and its status as an unconventonal pest of agricultural in and around Beer- Sonty reserve forest, Haryana, India. Journal of Applied and Natural Science 1(2): 245-249.

Haque, N. (1990). Study on the ecology of wild ungulates of Keoladeo National Park, Bharatpur. Ph.D. Thesis. Centre for Wildlife and Ornithology, Aligarh Muslim University, Aligarh. 308 pp.

Hussain, W. (2014). Special lecture in Wildlife Department, Former Head Department of Botony, Aligarh Muslim University, Aligarh, India.

International Union for Consevation of Nature (2014). www.iucnredlist.org/initiatives/mammals

Khan, I. (1992). Distribution and Crop raiding behaviour of nilgai in western U.P. in the village of Aligarh district. M.Phil. Dissertation, Aligarh Muslim University, Aligarh. $81 \mathrm{pp}$.

Khan, J.A. (1996). Factors governing habitat occupancy of ungulates in Gir lion Sanctuary, Gujarat, India. International Journal of Ecology and Environmental Science. 22: 73-83.

Khan, J.A. Chellam, R., and Johnsingh, A.J.T. (1995). Group size and age-sex composition of three major ungulate species in Gir Lion Sanctuary, Gujarat, India. Journal of Bombay Natural History Society 92: 295-302.

Khan, K.A. (2014). Current status and distribution of Nilgai 
in Aligarh District. M.Phil Dissertation Aligarh Muslim University, Aligarh.

Menon, V. (2014). Indian Mammals. A field guide. Hachette Book publishing India Ltd, 528 pp.

Prater, S.H. (1971). The Book of Indian Animals. Bombay Natural History Society, Bombay, India.

Qureshi, M.Q. (1991). Population status and movement of nilgai around the village Ghursikaran near Aligarh University. M.Phil. Dissertation, Aligarh Muslim University, Aligarh.

Sankar, K. (1994). The ecology of three large sympatric herbivores (chital, sambar, nilgai) with special reference to reserve management in Sariska Tiger Reserve, Ra- jasthan. Ph.D. Thesis. University of Rajasthan, Jaipur.

Schaller, G.B. (1967). The Deer and the Tiger. University of Chicago Press, Chicago. 370 pp.

Sheffield, W.J., Fall, B.A. and Brown, B.A. (1983). The Nilgal Antelope. The Caesar Kleberg Program in Wildlife Ecology and Department of Wildlife and Fisheries Sciences. The Texas A\&M University. 100 pp.

Singh, R. (1995). Some studies on the ecology and behaviour of Nilgai with an assessment of damage to agricultural crop and development of strategy for damage control in south western Haryana. Ph.D. Thesis, Aligarh Muslim University, Aligarh. 